International Journal of Agriculture, Environment and Bioresearch

Vol. 4, No. 04; 2019

ISSN: $2456-8643$

\title{
EFFECT OF BAGGING TIME ON FRUIT QUALITY AND SHELF LIFE OF MANGO (MANGIFERA INDICA L.) CV. LANGRA IN BANGLADESH
}

\author{
Md.Tariqul Islam ${ }^{1 *}$, Md. Shamsuzzoha ${ }^{2}$, Md. Shazadur Rahman ${ }^{3}$, Md. Abdul Bari ${ }^{4}$, Mst. Moli Akter ${ }^{1}$, Afifa \\ khatun5, Roksana Huque ${ }^{5}$, Md. Sorof Uddin ${ }^{6}$ \\ ${ }^{1}$ Department of Horticulture, Hajee Mohammad Danesh Science and Technology University, Dinajpur 5200, \\ Bangladesh \\ ${ }^{2}$ Departments of Chemistry, Hajee Mohammad Danesh Science and Technology University, Dinajpur 5200, \\ Bangladesh \\ ${ }^{3}$ Departments of Agricultural Chemistry, Hajee Mohammad Danesh Science and Technology University, Dinajpur \\ 5200, Bangladesh \\ ${ }^{4}$ Insect Biotechnology Division, Institute of Food and Radiation Biology, Atomic Energy Research Establishment, \\ Savar, Dhaka 1349 \\ ${ }^{5}$ Food Technology Division, Institute of Food and Radiation Biology, Atomic Energy Research Establishment, \\ Savar, Dhaka 1349 \\ ${ }^{6}$ Regional Agricultural Research Station, Bangladesh Agricultural Research Institute, Akbarpur, Moulvibazar
}

http://doi.org/10.35410/IJAEB.2019.4424

\begin{abstract}
The present experiment titled "pre harvest bagging enhanced quality and shelf life of mango cv. Langra" was conducted during the year 2017 at the mango orchard near Hajee Mohammad Danesh Science and Technology University, Dinajpur, Bangladesh. The research was carried out in the Randomized Complete Block Design with three replications. Mango fruits were bagged at 35, 45 and 55 days after fruit set with different types of bags which constituted various treatments viz.: T1: Transparent polythene bag, T2: White paper single layered bag, T3: Brown paper double layered bag, T4: control (no bagging). In fruit physical parameter result bagged at 35 days after fruit set with white paper and brown paper bag recorded maximum fruit length (97.93 and $103.5 \mathrm{~mm})$, fruit diameter $(79.27$ and $84.85 \mathrm{~mm})$, fruit weight $(311.66 \mathrm{~g}$ and $329.2 \mathrm{~g}$ ), pulp weight (278.9 $\mathrm{g}$ and $289.8 \mathrm{~g}$ ) respectively, and minimum result was found in polythene bag and control. Meanwhile in fruit chemical parameter of total sugar, reducing and non-reducing sugars, total soluble solids, ascorbic acid, $\mathrm{pH}$ and $\beta$-carotene were improved over control. Brown paper bag changed fruit color. The sensory qualities in fruits of brown and white paper bags were improved over control. Fruits treated with brown paper bag showed shelf life upto 11 days with lowest weight loss and good physical quality as against 6days of unbagged fruits (control). These results specify that fruit bagging can improve fruit quality through diminution in disease and insect-pest infestation and shelf life of mango cv. Langra.
\end{abstract}

Keywords: Bagging time, Fruit quality, Shelf life, Mango.

\section{INTRODUCTION}


Mango (Mangifera indica L.) belonging to the family Anacardiaceae, commonly known as the "King of fruits"[1], is a popular tropical fruit, especially in Asia. In Bangladesh, it's one of the most important commercial fruits and choice fruit for all age's people. Currently, there are about 41676 hectares of land occupied with mango orchard and produced about 1288315 ton [2]. The area under mango cultivation is increasing every year but safe and quality mango production not increased. Mango fruits and trees are subject to several animate and inanimate diseases. The outbreak of different mango diseases and insect-pest attack reduce the target mango yield every year. To control these problems farmers are using 15-62 times pesticides in their mango orchard and it's increasing as alarming ratio [3]. To prevent the losses caused by biotic and abiotic factors, several good agricultural practices are becoming popular throughout the World [4]. Furthermore, the development of alternative techniques to improve the appearance and quality of fruits and to reduce diseases and insect infestations is becoming increasingly important as consumer anxiety over the use of manmade agro-chemicals and environmental awareness increases. Thus, more emphasis is being placed on reducing the use of pesticides to ensure worker safety, consumer health, and environmental protection [4]. An attractive, spotless and pest free fruits of this variety fetch premium rate in the market. In recent years, the climatic aberrations such as sudden rise in the temperature and humidity, abnormal rains especially during fruit development are often experienced. It had not only affected the external appearance of the fruit but also aggravated the pest such as mealy bugs and physiological disorder like spongy tissue which further added in the losses. The affected fruits gain poor price in the market and such fruits are also rejected for processing. It causes serious economic loss to mango growers.

Among several such alternatives, the pre-harvest bagging technique of fruits has been used extensively in several fruit crops to improve skin color and to reduce the incidence of diseases, insect pests, mechanical damages, sunburn of the skin, agrochemical residues on the fruits, and bird damages [5]-[10]. Therefore, the present research work was undertaken to compare the effectiveness of different time of bagging in mango fruit (Mangifera indicaL.) cv. Langra

\section{MATERIALS AND METHODS}

The research work was conducted at different mango orchards in Dinajpur, Bangladesh during April to July, 2017. Chemical analyses were conducted at the laboratory of Atomic Energy Commission, Savar, Dhaka and other parameters were evaluated at the Department of Horticulture, HSTU, Dinajpur. Mango cv. Langra used as test materials. The experiment was constructed in Randomized Block Design with four treatments replicated three times with a unit of 10 fruits per treatment per replication. Different types of bags were constituted the treatments viz.: $\mathrm{T}_{1}$ : Transparent polythene bag, $\mathrm{T}_{2}$ : White paper single layered bag, $\mathrm{T}_{3}$ : Brown paper double layered bag, $\mathrm{T}_{4}$ : Non-bagged (control). Uniformly grown fruits $(35,45$ and 55 days after fruit set) were selected for bagging. The sizes of bags were $25 \times 20 \mathrm{~cm}$. Before bagging two perforations $(\leq 4 \mathrm{~mm}$ diameter) was made for proper ventilation at the bottom of polythene bag and muslin cloth bag. White and brown paper bags were not perforated. The particular bags were wrapped properly at the stalk of each fruit of respective treatments so that it would not be fall down as well as there would not be open space. Five fruits were randomly selected per treatment per replication to record various physical and chemical compositions which were estimated by the following procedures. 


\subsection{Physical parameters}

Length and diameter of fruit were measured with the help of digital varner caliper and expressed in millimeter $(\mathrm{mm})$. Weight of fruit and pulp was recorded by using electronic balance and expressed in grams $(\mathrm{g})$.

Weight Loss (\%): Weight of fruits was recorded with the help of physical balance and weight loss per cent was calculated by using the following standard procedure mentioned in AOAC (2000)[11].

$$
\text { Weight loss }(\%)=\frac{\text { Initial fruitweight }(\mathrm{g}) \text {-Weight of fruit on observation day/(g) }}{\text { Initial fruit weight }(\mathrm{g})} \times 100
$$

\subsection{Chemical composition}

\subsubsection{Total sugars}

Total sugar content of mango pulp was estimated by Anthrone reagent as per the method given by Hansen and Moller (1975)([12]). D- Glucose at the concentration of 20 to $100 \mathrm{~g}$ ml-1 was used to prepare the standard curve.

\subsubsection{Reducing sugars}

Total reducing sugar content of the samples was determined according to the classical and widely used method [13]. Briefly, mango pulps were homogenized with benzoic acid solution $(0.2 \%)$. An aliquote of the filtrate was mixed with the copper reagents (a mixture of alkaline Rochelle salt and acidic $\mathrm{CuSO}_{4}$ ). After heating in boiling water (15 min) and cooling, arsenomolybdate color reagent was added. Finally a blue color produced, the absorbance measured at $520 \mathrm{~nm}$ and compared with a set of standard (glucose).

\subsubsection{Non-reducing sugar}

Non reducing sugar content was determined by subtracting the reducing sugar content from total sugar content [14]. Non-reducing sugar content was determined by using the following formula. $\%$ Non-reducing sugar $=(\%$ Total sugar- $\%$ Reducing sugar $) \times 0.95$

\subsubsection{Total soluble solid (TSS)}

Total soluble solids were found out by using Erma Hand Refract meter ( 0 to $32^{\circ}$ Brix) and expressed in ${ }^{\circ}$ Brix [15].

\subsubsection{Ascorbic acid (mg/100g of Fruit pulp)}

Ascorbic acid was estimated as described by [16] Mango pulp (5g) was mixed with $5 \mathrm{ml}$ of $20 \%$ metaphosphoric acid solution and filtered. The filtrate $(5 \mathrm{ml})$ was put in a small beaker and shaken with 2 drops of phenolphthalein solution and titrated against 2, 6-indophenol until pink color developed. Results were expressed on a fresh weight basis as mg ascorbic acid equivalent per $100 \mathrm{~g}$ sample.

$$
\text { Vit } C(\mathrm{mg} / 100 \mathrm{~g})=\frac{0.5 \times \text { TitratvolumeunknownsolnX Made volume of unknownsample }}{\text { Titrat volume known soln X Alikuot takenX Sample weight }} \times 100
$$

\subsection{6 $\beta$-Carotene $(\mu \mathrm{g} / 100 \mathrm{~g}$ of pulp)}

$\beta$-carotene in mango pulp was determined according to the method of [17]. One gram of pulp was mixed with $10 \mathrm{ml}$ of acetone: hexane mixture (4: 6) and vortex for 5 minutes. The mixture was filtered and absorbance was measured at $453 \mathrm{~nm}, 505 \mathrm{~nm}$ and $663 \mathrm{~nm}$. 
B-carotene $(\mathrm{mg} / 100 \mathrm{ml})=0.216 \mathrm{~A}_{663}-0.304 \mathrm{~A}_{505}+0.452 \mathrm{~A}_{453}$

\subsection{7 $\mathrm{pH}$ of fruit juice}

The $\mathrm{pH}$ of each sample was determined by digital pH meter (JENWAY 3510). Fruit juice was made for each sample by homogenizing $10 \mathrm{~g}$ of sample in a homogenizer. The value was noted after adjusting and stabilizing the $\mathrm{pH}$ meter.

\subsubsection{Sensory evaluation}

The ripe fruits were also examined for their sensory qualities for assessing color, flavor and texture by panel of five judges with nine point Hedonic Scale viz. 1-Dislike extremely, 2-Dislike very much, 3-Dislike moderately, 4-Dislike slightly, 6-Like slightly, 7-Like moderately, 8-Like very much and 9-Like extremely [18].

\subsubsection{Shelf life of fruits (Days)}

Mature fruits were harvested at 80-85 percent maturity. Twenty harvested mature fruits of each treatment were ripened at ambient temperature by using plastic crates with perforation and traditional paddy straw as ripening material. At the bottom, $2.5 \mathrm{~cm}$ layer of paddy straw was made on which fruits were arranged. Simultaneously, two more layers were kept on the first layer. After ripening the various observations viz. shelf life (days) and incidence of mealy bug (\%) were recorded. The end of shelf life was noted when the fruits were spoiled.

\subsubsection{Disease incidence}

Diseases incidence means percentage of fruits infected with disease. This was measured by calculating the percentage of fruits infected in each replication of each treatment. The diseased fruits were identified symptomatically. The disease incidence was calculated as follow:

Disease incidence $(\%)=\frac{\text { Number of infected fruits in each replication }}{\text { Total number of fruits in each replication }} \times 100$

\subsubsection{Statistical analysis}

The data were analysed by partitioning the total variance with the MSTATC programme. The treatment means were compared using Turkey's Test.

\section{RESULTS AND DISCUSSION}

\subsection{Length of fruit (mm)}

The treatment of brown paper bag and white paper bag were gave the maximum fruit length $(103.5 \mathrm{~mm}$ and $97.93 \mathrm{~mm}$, respectively) at 35 days after fruit set. The treatment of control gave the fruit length $(92.4 \mathrm{~mm})$. However, minimum fruit length was recorded in the treatment of polythene bag $(88.2 \mathrm{~mm})$ at 45 and 55 days after fruit set(Table 1$)$.

Table 1. Effects of pre-harvest bagging on physical parameters of mango cv. Langra at ripe stage

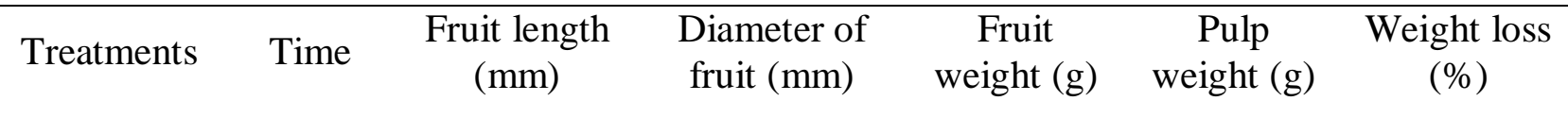


International Journal of Agriculture, Environment and Bioresearch

Vol. 4, No. 04; 2019

ISSN: $2456-8643$

\begin{tabular}{|ccccccc|}
\hline No bagging & & $92.40 \mathrm{abc}$ & $74.13 \mathrm{bc}$ & $264.9 \mathrm{~cd}$ & $214.9 \mathrm{cde}$ & $9.260 \mathrm{~cd}$ \\
\hline $\begin{array}{c}\text { Polythene } \\
\text { bag }\end{array}$ & 35 days & $88.20 \mathrm{abc}$ & $73.40 \mathrm{bc}$ & $248.6 \mathrm{de}$ & $207.6 \mathrm{def}$ & $10.20 \mathrm{bcd}$ \\
& 55 days & $84.27 \mathrm{c}$ & $68.67 \mathrm{c}$ & $200.4 \mathrm{f}$ & $164.2 \mathrm{~g}$ & $13.94 \mathrm{a}$ \\
\hline $\begin{array}{c}\text { White } \\
\text { paper bag }\end{array}$ & 35 days & $97.93 \mathrm{abc}$ & $79.27 \mathrm{ab}$ & $311.6 \mathrm{~b}$ & $278.9 \mathrm{a}$ & $12.69 \mathrm{ab}$ \\
& 55 days & $87.53 \mathrm{bc}$ & $74.93 \mathrm{bc}$ & $246.3 \mathrm{de}$ & $205.1 \mathrm{def}$ & $14.51 \mathrm{a}$ \\
$\begin{array}{c}\text { Brown } \\
\text { paper bag }\end{array}$ & 45 days & $99.73 \mathrm{abc}$ & $72.00 \mathrm{bc}$ & $238.6 \mathrm{e}$ & $197.6 \mathrm{ef}$ & $8.757 \mathrm{~d}$ \\
\hline LSD & 55 days & $101.0 \mathrm{ab}$ & $79.27 \mathrm{ab}$ & $273.5 \mathrm{c}$ & $226.7 \mathrm{bc}$ & $7.560 \mathrm{~d}$ \\
CV\% & & 13.69 & 7.532 & 17.52 & 16.39 & 2.899 \\
\hline
\end{tabular}

Means followed by the same letter(s) within each column didn't significantly differ at 5\% level.

\subsection{Diameter of fruit ( $\mathrm{mm})$}

Pre-harvest fruit bagging with brown paper and white paper bag gave the maximum $(84.85 \mathrm{~mm}$ and $79.27 \mathrm{~mm}$ ) fruit diameter over control and polythene bag $(74.13 \mathrm{~mm}$ and $73.40 \mathrm{~mm})$ at 35 days after fruit set which is statistically similar with 45 days after fruit. The diameter of fruit was slightly decreased at 45 and 55 days after fruit set (Table 1).

\subsection{Weight of fruit (g)}

The maximum fruit weight was found in the treatment of brown paper bagat 35 days after fruit set $(329.2 \mathrm{~g})$ and minimum in the polythene bag treatment (248.6 g) (Table1).Bagging increased fruit weight, size over control fruits[19].

\subsection{Pulp weight (g)}

The maximum pulp weight was found in the treatment of brown paper bag $(289.8 \mathrm{~g})$ which was statistically similar with the treatment of white paper bag (278.9 g) at 35 days after fruit set.

The minimum was found in the treatment of polythene bag $(164.2 \mathrm{~g})$ at 55 days after fruit set which was also statistically different with the treatment of control (214.9 g) (Table1).

3.5 Weight loss (\%)

The maximum weight loss was found in the treatment of white paper bag $(14.51 \%)$ which was statistically similar with the treatment of polythene bag with the values $13.94 \%$. The lowest weight loss was found in the treatment of brown paper bag (7.56\%) at 55 days after fruit set (Table1). These findings are accordance with some previous reports that the effects of preharvest bagging increased fruit growth, size, and weight [20]-[22],[9],[23],[5]-[6].

3.6 Total sugars $(\%)$ 
The total sugars were the highest in the white paper bag treatment $(14.82 \%)$ at 45 days after fruit set (Table 2). It was the lowest in the polythene bag treatment (10.44\%). Earlier, Harhash and Al-obeed (2010)[21]reported that date palm fruit bagged with blue color bag showed the highest total sugars as compared to control.

Table 2. Effects of pre-harvest bagging on chemical composition of mango cv. Langra at ripe stage

\begin{tabular}{|c|c|c|c|c|c|c|c|}
\hline Treatments & Time & $\begin{array}{c}\text { Total } \\
\text { sugars } \\
(\%)\end{array}$ & $\begin{array}{l}\text { Reducing } \\
\text { sugars }(\%)\end{array}$ & $\begin{array}{c}\text { Ascorbic } \\
\text { acid } \\
(\mathrm{mg} / 100 \mathrm{~g})\end{array}$ & $\begin{array}{c}\text { TSS(\% } \\
\text { Brix) }\end{array}$ & Pulp pH & $\begin{array}{c}\beta- \\
\text { carotene } \\
(\mu \mathrm{g} / 100 \\
\mathrm{g})\end{array}$ \\
\hline $\begin{array}{c}\text { No } \\
\text { bagging }\end{array}$ & & $13.91 \mathrm{ab}$ & $2.90 \mathrm{~b}$ & $41.19 \mathrm{a}$ & $15.34 \mathrm{a}$ & $5.853 \mathrm{a}$ & $598.2 \mathrm{a}$ \\
\hline \multirow{3}{*}{$\begin{array}{l}\text { Polythene } \\
\text { bag }\end{array}$} & 35 days & $13.22 \mathrm{abc}$ & $1.95 \mathrm{~cd}$ & $40.17 \mathrm{a}$ & $16.89 \mathrm{a}$ & $5.210 \mathrm{~b}$ & $608.4 \mathrm{a}$ \\
\hline & 45 days & $13.83 \mathrm{ab}$ & $1.80 \mathrm{~d}$ & $38.44 \mathrm{a}$ & $17.03 \mathrm{a}$ & $5.297 \mathrm{~b}$ & $602.0 \mathrm{a}$ \\
\hline & 55 days & $10.44 \mathrm{c}$ & $2.21 \mathrm{~cd}$ & $40.21 \mathrm{a}$ & $15.49 \mathrm{a}$ & $5.310 \mathrm{~b}$ & $614.6 \mathrm{a}$ \\
\hline \multirow{3}{*}{$\begin{array}{c}\text { White } \\
\text { paper bag }\end{array}$} & 35 days & $10.83 \mathrm{bc}$ & $1.95 \mathrm{~cd}$ & $40.21 \mathrm{a}$ & $16.22 \mathrm{a}$ & $5.310 \mathrm{~b}$ & $613.4 \mathrm{a}$ \\
\hline & 45 days & $14.82 \mathrm{a}$ & $2.73 \mathrm{~b}$ & $44.74 \mathrm{a}$ & $17.11 \mathrm{a}$ & $5.310 \mathrm{~b}$ & $603.4 \mathrm{a}$ \\
\hline & 55 days & $13.50 \mathrm{abc}$ & $2.16 \mathrm{~cd}$ & $39.65 \mathrm{a}$ & $16.13 \mathrm{a}$ & $5.220 \mathrm{~b}$ & $611.4 \mathrm{a}$ \\
\hline \multirow{3}{*}{$\begin{array}{c}\text { Brown } \\
\text { paper bag }\end{array}$} & 35 days & $12.26 \mathrm{abc}$ & $2.25 \mathrm{c}$ & $38.67 \mathrm{a}$ & $15.36 \mathrm{a}$ & $5.400 \mathrm{~b}$ & $616.3 a$ \\
\hline & 45 days & $10.84 \mathrm{c}$ & $3.28 \mathrm{a}$ & $42.57 \mathrm{a}$ & $18.78 \mathrm{a}$ & $5.273 b$ & $611.0 \mathrm{a}$ \\
\hline & 55 days & $12.76 \mathrm{abc}$ & $3.63 \mathrm{a}$ & $41.41 \mathrm{a}$ & $15.68 \mathrm{a}$ & $5.403 \mathrm{~b}$ & $611.0 \mathrm{a}$ \\
\hline LSD & & 2.902 & 0.3748 & 6.747 & 4.028 & 0.3387 & 24.83 \\
\hline CV\% & & 13.32 & 8.68 & 9.62 & 14.14 & 3.69 & 2.40 \\
\hline
\end{tabular}

Means followed by the same letter(s) within each column didn't significantly differ at 5\% level.

3.7 Reducing sugars (\%)

The highest reducing sugars were recorded in brown paper bag (3.63\%) at 55 days after fruit set which is statistically identical with 45 days while the lowest was recorded in the polythene bag $(1.80 \%)$ at 45 days after fruit set (Table 2). Similar findings were found in some previous research [23],[5]. They reported that fruits of newspaper and white paper bag exhibited the maximum reducing sugars at ripe stage in mango due to pre-harvest bagging treatments.

\subsection{Ascorbic acid (mg/100g)}

There was no significant different among the treatments (Table2). The highest ascorbic acid content was recorded in the treatment of white paper bag $(44.74 \mathrm{mg} / 100 \mathrm{~g})$ at 45 days after fruit 
set which was found statistically at par with brown paper bag $(42.57 \mathrm{mg} / 100 \mathrm{~g})$ while the lowest was recorded in the polythene bag $(38.44 \mathrm{mg} / 100 \mathrm{~g})$. The above results are very close to the findings of [5],[23]-[24] in mango.

\subsection{Total soluble solid (\% Brix)}

There was no significant different among the treatments (Table 2). The fruits of brown paper and white paper bag showed the highest soluble solids content $(18.78 \%$ Brix and $17.11 \%$ Brix, respectively) while lowest total soluble solids was recorded in control (15.34 \% Brix) at 45 days after fruit set. The findings revealed that percent total soluble solids increased sharply from harvest to ripe fruits have got support of [25] who mentioned that TSS increase initially and declined later on. Similar finding was recorded in some previous studies [5],[23].

\subsection{Pulp pH}

There was no significant difference among the treatments (Table2). The content of pulp $\mathrm{pH}$ in the control treatment (5.85) is higher than the other treatments of fruit bagging with brown paper bag (5.40), white paper bag (5.31) and polythene bag (5.31) (Table-2).

\subsection{1 $\beta$-carotene $(\mu \mathrm{g} / 100 \mathrm{~g})$}

The treatments were statistically non-significant variation in respect of $\beta$-carotene (Table2). The highest $\beta$-carotene content at 35 days after fruit set was recorded in the treatment of brown and white paper bag $(616.3 \mu \mathrm{g}$ and $614.6 \mu \mathrm{g}$, respectively) while the lowest was recorded in the non bagged control fruits $(598.2 \mu \mathrm{g})$. These findings are accordance with previous reports that a flesh lycopene and $\beta$-carotene content was increased due to pre-harvest bagging treatments in mango [26],[23],[5].

\subsection{Shelf life and disease incidence}

The maximum shelf life was found in the treatment of brown paper bag (11 days) while the minimum was found in the treatment of polythene bag (5 days) at 35 days after fruit set due to the early retention of the fruit. Islam et al.(2017a)[5] reported that pre-harvest bagging delayed ripening resulting in extended shelf life mango. The fruits of brown paper bag and white paper bag were free from fruit fly infestation at 35 and 45 days after fruit set but at 55 days showed in less infestation. The maximum incidence of fruit fly $(8.62 \%)$ and anthracnose $(32.03 \%)$ was recorded in control. The maximum infection of stem end rot was recorded in polythene bag $(39.27 \%)$ at 55 days after fruit set. The fruit bagging with brown paper bag at 45 days after fruit set had the lowest infection $(0.40 \%)$ of stem end rot which is statistically identical with 35 days.(Table 3).Bagging modified the microenvironment near fruit especially in respect to temperature and humidity. The longer shelf life of bagged fruits indicated that the effect of bagging persisted after ripening. Bagging provided physical barrier between fruit and pests. In mango cv. Keitt white paper bags at approximately 100 days before harvest reduced anthracnose and stem end rot [27].

Table 3. Effect of pre-harvest bagging on shelf life and different disease incidence of mango cv. Langra at ripe stage

\begin{tabular}{|lccccc|}
\hline Treatments & Time & $\begin{array}{c}\text { Shelf life } \\
\text { (days) }\end{array}$ & $\begin{array}{c}\text { Stem end rot } \\
\text { Anthracnose }\end{array}$ & $\begin{array}{c}\text { Fruit fly } \\
\text { infestation }\end{array}$ \\
& & $(\%)$ & $(\%)$ & $(\%)$ \\
\hline
\end{tabular}


ISSN: $2456-8643$

\begin{tabular}{|cccccc|}
\hline No bagging & & $6.00 \mathrm{~d}$ & $34.27 \mathrm{~b}$ & $32.03 \mathrm{a}$ & $8.62 \mathrm{a}$ \\
\hline \multirow{3}{*}{ Polythene bag } & 35 days & $5.00 \mathrm{~d}$ & $27.10 \mathrm{c}$ & $4.86 \mathrm{c}$ & $1.30 \mathrm{~d}$ \\
& 45 days & $6.33 \mathrm{~d}$ & $25.43 \mathrm{c}$ & $5.43 \mathrm{c}$ & $3.60 \mathrm{c}$ \\
& 55 days & $7.33 \mathrm{~cd}$ & $39.27 \mathrm{a}$ & $5.54 \mathrm{c}$ & $9.00 \mathrm{a}$ \\
\hline \multirow{3}{*}{ White paper bag } & 35 days & $9.00 \mathrm{bc}$ & $15.27 \mathrm{~d}$ & $3.00 \mathrm{~cd}$ & $0.00 \mathrm{~d}$ \\
& 45 days & $8.00 \mathrm{~cd}$ & $10.77 \mathrm{e}$ & $3.60 \mathrm{c}$ & $0.00 \mathrm{~d}$ \\
& 55 days & $8.00 \mathrm{~cd}$ & $15.10 \mathrm{~d}$ & $4.10 \mathrm{c}$ & $5.96 \mathrm{~b}$ \\
\hline \multirow{3}{*}{ Brown paper bag } & 35 days & $11.00 \mathrm{a}$ & $1.13 \mathrm{f}$ & $0.170 \mathrm{e}$ & $0.00 \mathrm{~d}$ \\
& 45 days & $10.66 \mathrm{ab}$ & $0.40 \mathrm{f}$ & $0.00 \mathrm{e}$ & $0.00 \mathrm{~d}$ \\
& 55 days & $10.00 \mathrm{ab}$ & $2.17 \mathrm{f}$ & $0.77 \mathrm{de}$ & $4.88 \mathrm{bc}$ \\
\hline LSD & & 1.761 & 3.54 & 2.513 & 1.458 \\
CV\% & 15.34 & 10.20 & 15.81 & 19.50 \\
\hline
\end{tabular}

Means followed by the same letter(s) within each column didn't significantly differ at $5 \%$ level.

\subsection{Sensory evaluation}

A way to get better final mango quality traits such as colour, appearance, flavour and overall expression were significant variation among various bagging treatments while texture and sweetness were non-significant. Beside, brown paper bag showed less sweetness compared to unbagged control at different time of bagging after fruit set. It indicated that the organoleptic qualities of fruits were affected by pre-harvest bagging in mango (Table 4).

Table 4. Effect of pre-harvest fruit bagging on sensory evaluation in fruits of mango cv. Langra at ripe stage

\begin{tabular}{|cccccccc|}
\hline Treatments & Time & Color & Texture & Appearance & Sweetness & Flavour & $\begin{array}{c}\text { Overall } \\
\text { Impression }\end{array}$ \\
\hline No bagging & & $6.330 \mathrm{bc}$ & $7.000 \mathrm{a}$ & $5.330 \mathrm{c}$ & $7.670 \mathrm{a}$ & $7.000 \mathrm{abc}$ & $4.330 \mathrm{de}$ \\
\hline $\begin{array}{c}\text { Polythene } \\
\text { bag }\end{array}$ & 45 days & $4.000 \mathrm{e}$ & $7.000 \mathrm{a}$ & $3.000 \mathrm{~d}$ & $7.330 \mathrm{a}$ & $5.330 \mathrm{c}$ & $3.330 \mathrm{e}$ \\
& 55 days & $3.000 \mathrm{e}$ & $7.670 \mathrm{a}$ & $3.330 \mathrm{~d}$ & $7.330 \mathrm{a}$ & $6.330 \mathrm{bc}$ & $5.330 \mathrm{~cd}$ \\
& & $7.000 \mathrm{a}$ & $3.000 \mathrm{~d}$ & $6.670 \mathrm{a}$ & $5.330 \mathrm{c}$ & $5.000 \mathrm{~d}$ \\
\hline
\end{tabular}


International Journal of Agriculture, Environment and Bioresearch

Vol. 4, No. 04; 2019

ISSN: $2456-8643$

\begin{tabular}{|cccccccc|}
\hline & 35 days & $5.703 \mathrm{~cd}$ & $7.000 \mathrm{a}$ & $7.000 \mathrm{ab}$ & $7.330 \mathrm{a}$ & $7.000 \mathrm{abc}$ & $7.330 \mathrm{ab}$ \\
$\begin{array}{c}\text { White paper } \\
\text { bag }\end{array}$ & 45 days & $7.330 \mathrm{abc}$ & $7.000 \mathrm{a}$ & $7.000 \mathrm{ab}$ & $8.330 \mathrm{a}$ & $7.000 \mathrm{abc}$ & $7.670 \mathrm{ab}$ \\
& 55 days & $7.670 \mathrm{ab}$ & $7.000 \mathrm{a}$ & $7.000 \mathrm{ab}$ & $7.670 \mathrm{a}$ & $7.330 \mathrm{abc}$ & $6.670 \mathrm{bc}$ \\
\hline $\begin{array}{c}\text { Brown } \\
\text { paper bag }\end{array}$ & 45 days & $7.670 \mathrm{ab}$ & $7.670 \mathrm{a}$ & $8.330 \mathrm{a}$ & $7.000 \mathrm{a}$ & $8.670 \mathrm{a}$ & $8.670 \mathrm{a}$ \\
& 55 days & $8.330 \mathrm{a}$ & $7.670 \mathrm{a}$ & $7.330 \mathrm{a}$ & $7.000 \mathrm{a}$ & $7.670 \mathrm{ab}$ & $7.670 \mathrm{ab}$ \\
\hline LSD & & 1.542 & 1.976 & 1.300 & 1.792 & 1.842 & 1.398 \\
CV\% & & 14.85 & 16.16 & 13.09 & 14.43 & 15.99 & 13.52 \\
\hline
\end{tabular}

Means followed by the same letter(s) within each column didn't significantly differ at 5\% level.

\section{CONCLUSION}

Thus, it is concluded that the pre-harvest treatment with brown and white paper bagging were found to be the best to increase the fruits quality in respect of fruits weight, TSS, ascorbic acid, total sugarsand $\beta$-carotene, with minimum weight loss and less diseases incidence in mango fruits cv. Langra. Among all treatment, brown paper bag at 35 days provided the best performance for all parameters while without bagging in produced inferior. Therefore, the preharvest treatment of brown and white paper bagging are suggested to the mango traders and grower of Bangladesh for taking a quality production with prolonged shelf life to obtain a profitable price of mangoes in domestic and export markets.

\section{ACKNOWLEDGEMENT}

This work was supported by using the research grant of USAID Trust Fund and GoB through Ministry of Agriculture, Government of the People's Republic of Bangladesh. We would like to thanks to the World Bank for arranging the grand fund and supervising the CRGs by BARC (ID 444). It is worthwhile to mention the cooperation and quick responses of PIU-BARC, NATP 2, in respect of field implementation of the sub-project in multiple sites.

\section{REFERENCES}

[1] Singh, H. Mango.ICAR. New Delhi, India, 1996.

[2] BBS. Year book of agricultural statistics-2016, Bangladesh Bureau of statistics, Statistics Division, Ministry of planning, Government of the people's Republic of Bangladesh, pp. 200, 2017.

[3] Uddin, M.S., Islam, M.S., Uddin, M.Z., Alam, M.A., Hossain, M.M., Rashid, M.H. Modern production technology of mango and its Marketing system. Regional Horticulture Research Station, BARI, Chapainawabganj, pp. 46, 2015. 
[4] Sharma, R.R., Singh, D., Singh, R. Biological control of postharvest diseases of fruits and vegetables by microbial antagonists. Biological Control, pp. 50, 205-221, 2009.

[5] Islam, M.T., Rahman, M.S., Shamsuzzoha, M., Chowdhury, A.K.M.M.B., Alom, R. Influence of pre-harvest bagging on fruit quality of Mango (Mangifera indica L.) cv. Mishribhog. International Journal of Biosciences, 11(3), pp. 59-68, $2017 \mathrm{a}$.

[6] Islam, M.T., Shamsuzzoha, M., Rahman, M.S., Haque, M.M. and Alom, R. In fluence of pre-harvest bagging on fruit quality of mango (Mangiferaindica L.) cv. Mollika.Journal of Bioscience and Agriculture Research, 15(1), pp. 1246-1254, $2017 \mathrm{~b}$.

[7] Jakhar, M.S., Pathak, S. Effect of pre-harvest nutrients application and bagging on quality and shelf life of mango (Mangifera indica L.) fruits cv. amrapali. Journal of Agricultural Science and Technology, 18, pp. 717-729, 2016.

[8] Nagaharshitha, D., Khopkar, R.R., Haldankar, P.M., Haldavanekar, P.C., Parulekar, Y.R. Effect of bagging on chemical properties of mango (Mangiferaindica L.) cv. alphonso.Agrotechnology 3, pp. 124, 2014.

[9] Sharma, R.R., Reddy, R.S.V. and Jhalegar, M.J. Pre-harvest fruit bagging: a useful approach for plant protection and improved post-harvest fruit quality. Journal of Horticultural Science and Biotechnology, 89(2), pp. 101-113, 2014.

[10] Xu, H.X., Chen, J.W. and Xie, M. Effect of different light transmittance paperbags on fruit quality and antioxidant capacity in loquat. Journal of the science of Food and Agriculture, 90, pp. 1783-1788, 2010.

[11] AOAC. Official Methods of Analysis. 17th Edition, Association of Official Analytical Chemists, Washington, DC, USA, 2000.

[12] Hansen, J. and Moller, I. Percolation of Starch and Soluble Carbohydrates from Plant Tissue for Quantitative Determination with Anthrone. Analytical Biochemistry, 68, pp. 87-94, 1975.

[13] Nelson, N. J. A photometric adaptation of the Somogyi method of the determination of glucose. Journal Biological Chemistry 153, pp. 357, 1944.

[14] Banik, A.K. Studies on pre and postharvest treatments on shelf life of mango with special reference to major diseases.Ph.D. Thesis, BCKV, West Bengal, pp. 52, 1995.

[15] AOAC. Official Methods of Analysis. Association of Official Analytical Chemists (12th Ed.) Washington, DC, USA, 2004.

[16] McHenry, E.W., Graham, M. Observation on the estimation of ascorbic acid by filtration. Biochemistry Journal, 29(9), pp. 2013-2019, 1935. 
[17] Nagata, M. and Yamashita, I. 1992. Simple method for simultaneous determination of chlorophyll and carotenoids in tomato fruit. Journal of Japanese Society of Food Science and Technology, https://doi.org/10.3136/nskkk1962.39.925, 39, pp. 925-928, 1992.

[18] Amerine, M.A., Pangborn, R.M. and Rocssler, E.B. Principles of sensory evaluation of food. London: Academic Press, 1965.

[19] Chonhenchob, V. Pre-harvest bagging with wavelength-selective materialsenhances development and quality of mango (Mangifera indica L.) cv. Nam Dok Mai. Journal of Science, Food and Agriculture, 91, pp. 664-671, 2011.

[20] Yang, W.H., Zhu, X.C., Bu, J.H., Hu, G.B., Wang, H.C., Huang, X.M. Effects of bagging on fruit development and quality in cross-winter offseason longan. Scientia Horticulturae, 120, pp. 194-200, 2009.

[21] Harhash, M.M., Al-Obeed, R.S. Effect of bunch bagging color on yield and fruit quality of date palm. American-Eurasian Journal of Agriculture and Environmental Science, 7, pp. 312-319, 2010.

[22] Zhou, J., Zhong, G., Lin, Z., Xu, H. The effects of bagging on fresh fruit quality of Canarium album. Journal of Food Agriculture and Environment, 10(1), pp. 505-508, 2012.

[23] Haldankar, P.M., Parulekar, Y.R., Alwala, K., Kad, M.S., Shinde, S.M., Lawande, K.E. Studies on influence of bagging of fruits at marble stage on quality of mango cv. alphonso. Journal of Plant Studies, 4, pp. 12-20, 2015.

[24] Sharma, R.R., Pal, R,K,, Asrey, R., Sagar, V.R., Dhiman, M.R., Rana, M.R. Pre-harvest fruit bagging influences fruit color and quality of apple cv. Delicious. Agricultural Science 4(9), pp. 443-448, 2013.

[25] Joshi, G. D. and Roy, S. K. Influence of maturity, transport and cold storage on biochemical composition of Alphonso mango fruit, Journal of Maharashtra Agricultural University, 13(1), pp. 12-15, 1988.

[26] Zhao, J.J., Wang, J.B., Zhang, X.C., Li, H.L,Gao, Z.Y. Effect of bagging on the composition of carbohydrate, organic acid and carotenoid contents in mango fruit. Acta Horticulturae, 992, pp. 537-554, 2013.

[27] Hofman, P.J., Smith, L.G., Joyce, D.C., Johnson, G.L. and Meiburg, G.F. Bagging of mango(Mangifera indica cv. 'Keitt') fruit influences fruit quality and mineral composition. Post-harvest Biological Technology, https://doi.org/10.1016/S09255214(97)00039-2, 12, pp. 83-91, 1997. 